\title{
Effects of Downsizing on Employee Performance of Selected Manufacturing Firms in Anambra State, Nigeria
}

\author{
Anekwe Rita Ifeoma ${ }^{1}$, Mukhtaruddin Mukhtaruddin ${ }^{2} \&$ J. Johny Natu Prihanto ${ }^{3}$ \\ ${ }^{1}$ Nnamdi Azikwe University, Nigeria \\ ${ }^{2}$ Universitas Sriwijaya, Indonesia \\ ${ }^{3}$ Universitas Multimedia Nusantara, Indonesia \\ Correspondence: Anekwe Rita Ifeoma, Nnamdi Azikwe University, Nigeria.
}

Received: June 23, 2019

Accepted: July 17, 2019

Online Published: December 15, 2019

doi:10.5430/rwe.v10n3p391

URL: https://doi.org/10.5430/rwe.v10n3p391

\begin{abstract}
The study examines the effects of downsizing and employee performance in selected manufacturing firms in Anambra state, Nigeria. The study seeks to: ascertain the extent of relationship that exists between job insecurity and absenteeism in selected manufacturing firms. Examine the extent of relationship that exists between staff redundancy and employee turnover in selected manufacturing firms. The sources of data collection were primary and secondary sources. Structured questionnaire and interview were used to elicit vital information from the respondent. The data were analyzed using descriptive statistics such as mean, simple percentage and standard deviation while the hypotheses were tested using simple regression. The major findings revealed a positive and statistically significant relationship between job insecurity on absenteeism in the studied manufacturing firms. There is a positive and statistically significant relationship between staff redundancy and employee turnover in the studied manufacturing firms. The study therefore concluded that increase in global competitiveness, together with advances in technology and ongoing changes in the environment, requires organizations to continuously adapt and be willing to change their structures, strategies, methods and practices to remain competitive.
\end{abstract}

Keywords: downsizing, employee performance, job insecurity, staff redundancy

\section{Introduction}

In the modern world, where competition allows organizations to work with efficiency and effectiveness, it has become pertinent for organizations to reduce their costs and improve their profitability by introducing modern cost cutting techniques irrespective of whether the organizations are public or private organization adopted downsizing as a corporate policy to reduce cost and improve employee performance.

Yu \& Park (2006) agreed that downsizing improves an organizations efficiency and profitability. One of the reasons adduced for this is cost elimination that accompany downsizing. The reduction of staff naturally reduces the labor costs and in turn increases financial income. Many scholars and policy makers' reported that the process of downsizing has major implications for the human resources of any organization (Bushra, 2010). Not only does it affect the psychological bond between employees and management, it also gives rise to severe stress and strain among the employees in an organization. Downsizing has become a stress inducing factor that severely affects the survivors' attitudes and behaviors at work place (Brockner 1998). It has resulted in reduced morale and trust of survivors for the organization. The survivors who are mainly responsible to revitalize the organization and provide customer satisfaction (Henkoff, 1994) tend to have lesser commitment towards the organization (Cascio 1993, Luthan \& Sommer, 1999, Wager 1998).

Downsizing is the conscious use of permanent personnel reductions in an attempt to improve efficiency and effectiveness of the organization. Downsizing is regarded by management as one of the preferred routes to turning around declining organizations, cutting costs, and improving organizational performance most often as a cost-cutting measure. According to Greenberg \& Baron, (2000), downsizing is likely to lead to disruptions in the workplace. Many companies consider the organization's profits by cutting down costs with all the attention firmly fixed on the need for change, the leaders are often blind to the impact of downsizing on people and their relationships and hence on the performance of the people. The trend toward employee reductions for reasons other than job performance (i.e., 
downsizing) began in earnest during the early 1980s, when many firms found themselves in the throes of a significant economic downturn often in the context of declining revenues, downsizing during this period was driven primarily by managers' beliefs and expectations that downsizing could preserve profitability by enhancing organizational efficiency and reducing costs. Downsizing during this era was prompted by dramatic slowdowns in business, it was thought to be temporary in nature even after economic recovery; however, the ensuing years witnessed continued and significant job loss. This trend has however, become a strategic weapon of mass cleaning adopted by most troubled organizations (DeWitt 1998, Freeman 1994, Harrigan, 1980). Since the 1980s, many organizations have downsized for different reasons such as global conditions, financial crisis, mismanagement, bankruptcy, high levels of competition, more organizations were known to have gone under before and after recession all increased the recourse to massive layoffs. Moreover, downsizing often rears its ugly head in other areas such as the times of merger and acquisitions. These have often been blamed on the recent advent of the internet and the outcomes of living in a globalized world where organizations struggle to continually adjust their products and services, as well as prices and costs of labor to stay not just competitive but profitable.

Downsizing has even become common in industrialized countries, such as Japan and Sweden, which have historically shown to have very stable employment practices (Weiss, 2008). Downsizing have been particularly used by American corporations (Budros, 1999; Cascio 1998), it has also become a common feature both in European countries (Filatochev, 2000; Vicente-Lorente\& Suarez-Gonzalez, 2007) and in some emerging countries (Ahmadjian\& Robinson, 2001; Lee, 1997). It has also been adopted all over the world even in companies in developing countries such as India, Indonesia, Thailand, Malaysia, South Korea and Nigeria. Since the early 2000's there has been a wave of global downsizing of employees in many organizations. The situation is not any different than what we have here in Nigeria, political instability, industrial strike action and economic reforms, recession have all contributed to the downsizing of the Nigerian workforce. Organizational downsizing has recently become an increasingly important issue that needs to be addressed to ensure fair employment practices. Companies worldwide have used downsizing to improve organizational competitiveness, profitability, effectiveness, efficiency as well as to reduce the size of their workforce. It has been argued that downsizing reduces organizational slack and operating costs, streamlines operations, and enhances effectiveness toward making an organization more competitive. Studies that support the position that downsizing can improve aspects of organizational efficiency or effectiveness include those by Baumol, (2003), Espahbodi, (2000), \&Wayhan\& Werner, (2000). It was on these backdrops that the study examines the effects of downsizing on employee performance.

Reduction of employees has become a potentially valuable way of securing a competitive advantage and improving both employees and organizational performance, downsizing has been in existence for a while now however, its effect on employee or organizational performance has brought mixed reactions in both developed and developing countries. This quagmire has led to uncertainty while considering downsizing as a tool of enhancing employee performance. Downsizing is one of the defensive strategies an organization can adopt to cut costs or to make the organization more productive and profitable. But the perceived outcomes might not be achieved in all organizations, which attempted to downsize their workforce because of disruptions in the workplace, which may result in stress, frustration, anxiety and anger in survived employees' (Kravitz, 1993 \&Burne, 1994). There is yet limited evidence to support that firms that deployed downsizing achieve better results in terms of return on investment, sales gains, or other objectively measurable. It is expected that the thoughts of layoffs will instigate some psycho-emotional effects among the employees the effect on the organizational performance notwithstanding. Employees face unfavorable effects as they have doubts regarding new or altered work assignments, adaptation in career paths, team changes and resultantly reduced their job efforts, job satisfaction and organizational commitment which lead to poor performance of employees as well as the organization. An increase in the perception of the employees about the job-insecurity leads to increase in absenteeism and decrease commitment towards their organization.

The broad objective of the study is to examine the effects of organizational downsizing on employee performance in selected manufacturing firms in Anambra state, Nigeria. Specifically, the study seeks to: 1) Ascertain the extent of relationship that exists between job insecurity and absenteeism in selected manufacturing firms in Anambra State, Nigeria. 2) Examine the extent of relationship that exists between staff redundancy and employee turnover in selected manufacturing firms in Anambra State, Nigeria. 


\section{Review of Related Literature}

\subsection{Conceptual Review}

\subsubsection{Organizational Downsizing}

Cascio (1993) defined downsizing as cutting and removal of job-positions, which does not include the retirement or voluntary resignation. According to Robin (1999) organizations downsize either by 'need' or by 'preference'. The former is the classic layoff which is due to adaptation in organizational structure, culture or technological change (for example, automation), however in the latter, organizations are not financially compelled to do so, but adopted the downsizing to enhance their productivity. Downsizing involves permanent and Intentional reductions in the workforce by management of the firms' internal labour force by using redundancies (Freeman and Cameron, 1993). Kozlowsky, smith et al (1993) has defined the process of downsizing as a deliberate organizational design carried out in order to reduce the workforce which in turn is focused on improving the performance of the organization.

According to Cameron (1994) it is a set of organizational activities undertaken by management in order to improve organizational efficiency employee productivity and overall organizational competitiveness. Downsizing comes under the category of those management tools targeted for achieving desired change, almost similar and synonym to " rightsizing" and " reengineering" (Cameron, 1994). Ryan \&Macky, 1998; Littler, (2000) fundamentally it refers to a deliberate reduction by management of a firm's size in terms of the number of employees it has (Kammeyer- Mueller, Liao \&Arvey, 2001). There are many ways in which an organisation can be downsized (Greenhalgh, Lawrence \& Sutton, 1988), including eliminating functions, cutting hierarchical levels (Tomasko, 1987) or 'delayering' (Littler, 2000; Littler et al.1997, eliminating business units, using natural attrition of employee combined with hiring freezes, offering early retirement incentives, and, most commonly, via redundancies (Appelbaum et al., 1999). All such practices represent a managerial strategy that affects the size of the firm's workforce (Cameron, Freeman \& Mishra, 1993) and whose primary purpose, either reactively or proactively, is to improve organizational performance (Littler, 2000; Kinnie, Hutchison \& Purcell, 1998). Downsizing is proxy with job insecurity and staff redundancy.

\subsubsection{Job Insecurity}

Job insecurity is one of the most common stressors concerning the uncertainty experienced over the future of one's job (Lee, 2006 and Capelli, 1999). The phenomenon of job insecurity has been considered as a perceived powerlessness to maintain desired continuity in a threatened job situation (Greenhalgh and Rosenblatt, 2004). Sverke and Hellgren (2002) view job insecurity as a perceptual phenomenon, reflecting the fear of involuntary job loss, with job insecurity thus representing an individual's perception of the employment situation being more insecure than he or she would prefer (Sverke and Hellgren, 2001). Job insecurity arising from the threat of losing a particular job may lead to loss of employment security if subsequent jobs prove hard to find (Bartley and Ferrie, 2001). Two distinct perspectives on the definition of job insecurity are presented, namely the global and the multidimensional perspectives (Ashford et al., 1989). Job insecurity signifies the threat of job loss or the endangerment of job continuity. Generally, this definition has been applied in the context of organizational crisis or change, in which job insecurity is considered as a first phase of the process of job loss (Ferrie, 1997). Job insecurity refers not only to the amount of uncertainty an employee feels about his or her job continuity, but also to the discontinuity of certain dimensions of the job or of valued conditions of the particular employment, such as opportunities for promotion, or the possibility of being laid off and losing one's work-related social network (Mauno et al., 2005).

\subsubsection{Staff Redundancy}

Redundancy occurs when employee lose his/her job due to the closure of a business or a reduction of the workforce. This can happen due to lack of work available or the financial circumstances of the firm. Redundancy situation arises where it is established that there is no longer a requirement for the work that the employee carries out and where a search for suitable alternative employment within the wider organisation has been exhausted and proved unsuccessful. A major disadvantage of redundancy is losing the expertise, knowledge and experience of workers who have been let go. An advantage of this can be that the remaining employee will feel and exhibit more loyalty towards the company and how it can be an opportunity for them to grow personally and professionally. Job redundancy is "the planned process of cutting back on human resources" (Hardy, 2001). Redundancy is a situation in which an employee or group of employees lose their jobs because their employer no longer needs them to carry out the employment for which they have been contracted. Employers may need to make employees redundant when the organisation requires fewer employees to carry out work of a particular kind, or certain business requirements have ceased. Absenteeism and turnover increase during times of redundancies as some people are unwilling to accept the serious implications redundancy has and the impending fear it could happen to them. When redundancy is being implemented into an 
organisation, issues will always arise. Issuing redundancies must be considered carefully. Harper (2009) writes about identifying the correct pool for redundancy selection.

\subsubsection{Employee Performance}

Performance is the outcome or contribution of employees to make them attain goals while performance may be used to define what an organization has accomplished with respect to the process, results, relevance and success. Performance is associated with quantity of output, quality of output, timeliness of output presenceattendance on the job, efficiency of the work completed and effectiveness of work completed" (Mathis \& Jackson 2009). Employee Performance is the successful completion of tasks by a selected individual or individuals, as set and measured by a supervisor or organization, to pre defined acceptable standards while efficiently and effectively utilizing available resource within a changing environment (Aguinis 2009). Kenney et al. (1992) stated that employee's performance is measured against the performance standards set by the organization. There are a number of measures that can be taken into consideration when measuring performance for example using of productivity, efficiency, effectiveness, quality and profitability measures (Ahuja 1992). Performance does not include the results of an employee's behavior, but only the behaviors themselves. Performance is about behaviour or what employees do, not about what employees produce or the outcomes of their work. Shirley, (2006), perceived that employee performance represents the general belief of the employee about his behavior and contributions in the success of organization. Employee performance may be taken in the perspective of three factors which makes possible to perform better than others, determinants of performance may be such as "declarative knowledge", "procedural knowledge" and "motivation". Managerial practices have positive impact on performance of individuals. Carlson et al. (2006) proposed five human resource management practices that affect performance which are setting competitive compensation level, training and development, performance appraisal, recruitment package, and maintaining morale.Grimaldi (2005) explains that managing employee performance includes: planning work and setting expectations, monitoring and measuring performance, developing the capacity to perform, periodically rating performance in a summary fashion, and recognizing and rewarding good performance. Practicing good employee performance requires proficiency in certain competencies. Competencies are observable, measurable patterns of skills, knowledge, abilities, behaviors, and other characteristics that an individual needs to perform work roles or occupational functions successfully. According to Huselid (2005), employee performance reminds people that being busy is not the same as producing results. It reminds us that training, strong commitment and lots of hard works alone are not results. The major contribution of managing employee performance is focused on achieving results useful products and services for customers inside and outside the organization. In the context of this study employee performance is proxy with absenteeism and employee turnover.

\subsubsection{Absenteeism}

Absenteeism is commonly defined as the failure of workers to report on the job when they are scheduled to work (Huczyunski and Fitzpatrick, 1989). Harrison and Price (2004) defined absence as, 'lack of physical presence at a behavioral setting when and where one is expected to be. According to Teixeira (2010), absenteeism is an expression to describe the absence of employees from work. This definition, although simplistic, translates a vital essence, when viewed by the perspective of the employer in the interest of this fundamental productivity or lack of it by the employee. For the company, the absence of employee undermines the purpose of the company as an organization capable of producing a particular good or service and represents additional costs to production or service delivery. Chiavenato (2002) refers to absenteeism as the total of the periods in which employees of a given organization are absent from work, not being the absence motivated by unemployment, prolonged illness or legal license. The author reflects a view of the law in effect, in which absences legally established and planned are not considered absenteeism. Tiwari (2014) defined absenteeism as absence of workers from the regular work without prior permission. Excessive absenteeism involves a considerable loss to the enterprise because work scheduled are upset and delayed and management has to give overtime wages to meet the delivery dates. Absenteeism is an unplanned, disruptive incident; but more specifically it can be seen as non -attendance when an employee is scheduled to work (Van Der Merwe and Miller, 1988). Nel, Dyk, Haasbroek, Schultz, Sono and Werner (2001) defined absenteeism as withdrawal behaviour when it is used as a way to escape an undesirable working environment. Two general perspectives inform understanding on absenteeism (Koslowsky 2009). The first views absenteeism as an indicator of work withdrawal, where workers reduce attendance as a result of unfavorable work attitudes, such as job dissatisfaction and low organizational commitment (Hulin 1991). A second perspective considers absenteeism as a result of work stress.

\subsubsection{Turnover}

Turnover as it "typically refers to the separation of an employee and sooner or from the firm" (Naumann, Henry and Ongori, 2007). Conversely turnover intention is define as a conscious and deliberate willingness to leave the 
organization (Ali and Baloch, 2008). Employee turnover occurs when there is need for employees to leave their jobs and must be replaced. Replacing exiting employees is a cost to the organizations and destructive to service delivery and this has a significant level of negative effect on the organization's performance. Man (2010), employee turnover measures the movement of workers in and out of employment with particular firm, the issue and interest in measuring such movement only arose when working for an employer (rather than self-employment). Bureau (2008), defined employee turnover as the rate at which an employer gains and losses employees. Furthermore, labour turnover according to Abssi and Hollman (2000) quoted in Ongori (2007) defined employees turnover as the rotation of workers around the labour market; between firms, jobs and occupations; and between the state of employment and unemployment.Employee turnover results in an extra work load for the remaining staff member's performance and on organizational effectiveness. Mathis and Jackson (2007) state that employees have to work extra hours to compensate for the work of those that have resigned which result in extra workload for the remaining employees. Turnover can be defined as the process in which employees leave the organization and have to be replaced by others (Warsi, 2009). Excessive turnover can be a very costly problem to the company, one with a major impact on productivity (Scott, 2007). But cost is not the only reason turnover is an important issue. Lengthy training times, interrupted schedules, additional overtime, mistakes and not having knowledgeable employees in place are some of the frustrations associated with excessive turnover which may be caused by lack of employee commitment (Tumwesigye, 2010).High employee turnover is of considerable concern for employers because it disrupts normal operations of the company, causes morale problems for that stick on, and increases the cost involved in selecting and training the replacements (Bosman, Buttendach, and Laba, 2008).

Turnover is the employee movement across the boundaries of an organization (Price, 1977). In most researches turnover is consider as the outward movement of employees instead of inward movement into the organizations. There are two major categories of turnover one is voluntary and the other one is involuntary turnover (Wiley 1993). Turnover whether it is voluntary or involuntary is costly for organizations. As Mobley (1982) has explained this as whether the turnover is voluntary in which employees resign themselves or involuntary in which they are terminated by their employer, organizations bear following costs as recruiting, hiring, training, retaining, loss of productivity during replacement search, loss of high performers and disruption of social and communication structures of organizations.

\subsection{Theoritical Framework}

The study is anchored on Equity theory of motivation.

Equity Theory of Motivation: The theory was propounded by Adam J. Stacy (1965). He advocated that individuals make comparisons on the rewards (output) given to them as a result of their contributions (input) with that of others to see whether it is fair or not. According to Adams theory of equity, an important factor in motivation is whether individual perceive the reward (fair treatment) as begin fair. One way of addressing this issues is through equity theory which refers to individual subjective judgments about the equity or fairness of the reward they get in relationship to the inputs (which includes many factor such as effort, experience, education and so on) in comparison with others. According to Adams (1965) felt injustice will lead to dissatisfaction, anger, and guilt. People will feel angry and dissatisfied when they are getting less of what they expect in comparison to what they input. The essential idea behind equity theory is that when individuals work for an organization they present certain inputs (e.g. abilities or job performance). Based on what they input in, people expect to get something in return, for example when people input high performance they expect to get a high pay and other benefits (Cropanzano 1993). Equity theory predicts that low rewards produce dissatisfaction; this would in turn motivate people to take action and reduce the discrepancy between their ratio and the ratio of the comparison other. Perry (1993) found a strong relationship between reward and job satisfaction. Equity theory is considered to be one of the most valid frameworks to understand human attitudes and motivation. According to Miner (1980), equity theory has the following characteristics such as prediction of performance, prediction of work satisfaction, construct validity, feasibility and utility. There should be a balance of the outcome/inputs relationship for one person in comparison with another person because at any time individuals feel inequity in outcome or that they are inadequately rewarded, they are bound to be dissatisfied which will eventually lead to reduction in the quality and quantity of input, quitting or leave the organization and resort to pilfering organizational resources, this will automatically affect employee performance and organization productivity. If people perceive the rewards as fair and equitable, they probably will continue at the same level of output. Explanation of dissatisfaction and low morale, internal perceptions of work environment causes people to form beliefs and attitudes. These cognitions, in turn, instigate and direct various work related behaviors (Pinder,1998). Motivation is a function of how a person sees self in comparison to other people. Feelings of inequity cause tension. The greater the inequity, the greater the tension and the greater the motivation to reduce it. How hard a person is willing to work is a function of comparisons to the effort of others. Based on the result of the comparison, a 
person may either work harder, or less hard, or maintain performance.

\section{Relevance of the theory to the study}

Surviving employees are more committed to the organization when they perceived that the leavers were adequately compensated and equitably treated. Greenberg (1990) also further reports that organizational surveys have indicated that the current job performance of employees is a critical factor in surviving employees' judgment of the fairness of the process. When employees perceived that the decisions guiding the layoff were unfair, and that the victims were inadequately cared for by the organization these tend to affect employees performance. Performance was most clearly adversely affected where downsizing had proceeded in a way which was considered unfair by employees and/or had produced an unstable work environment in which survivors perceived their continued future employment with the downsizing firm to be uncertain. On the other hand when employees perceived that downsizing process where done fairly and that the employees who were downsized are rewarded and cared for and that the employees who survive downsizing are assured of job security, good working environment and other benefits it will make them to be more committed to the organization and thus improved their performance.

\subsection{Emperical Review}

Robert \& Anne (2015) investigated the effect reduction of employees as a downsizing strategy on performance of employees of Barclays bank. The study adopted a survey research design. Data for the study were collected from a sample 183 employees of Barclays Bank South Rift Hub, Kenya. Questionnaires were used as the sole data collection instrument. The data that was collected from the field was analyzed using both descriptive and inferential statistics. The findings established that there was a strong positive correlation of 0.982 between reduction of employees and the dependent variable employee performance. The results indicated that higher levels of effective employee reduction leads to effective performance of commercial banks hence they need to consider applying downsizing. The results of this study shall therefore benefit the management of commercial banks to understand the effects of downsizing and put in place appropriate strategies to ensure that only the positive effects leading to improved performance are emphasized.

Sumera \& Faiza (2015) the study examined the effects of downsizing on job satisfaction of existing employees in banking sector of Pakistan. The sample of the current study is drawn from the banking sector of Pakistan and the data is gathered through questionnaires from the sample size of 80 employees. The data is analyzed by applying one sample t-test to identify the relationship between downsizing and job satisfaction of employees and the questionnaire reliability analyzed by applying Cronbach's alpha reliability in IBM SPSS version 19. The study used 5\% significance level. Results indicated that there is relationship between downsizing and job satisfaction of existing employees and downsizing effects on employee's job satisfaction, job security and communication in an organization. This study will enable the academicians, policy maker and management of an organization to understand the effects of downsizing on job satisfaction of employees and the study provided recommendations for the management to maintain and improve job satisfaction of the remaining employees in an organization after downsizing

Asuma \& Ayse (2016) conducted a research to examined how organizational downsizing affects survivors' commitment to the organization. A survey was conducted using five firms in the manufacturing industry in Kayseri (Turkey) that were undergoing downsizing. Data were obtained from 163 employees and was analyzed using SPSS 15.0. The survey revealed that employees' positive perceptions of organizational downsizing increased organizational commitment, including affective, continuance, and normative commitment.

Rehman \& Naeem (2012) have proposed a conceptual model of the after-effects of the downsizing on the survived employees of the organization. The proposed model is the logical integration of the inevitable after-effects of the downsizing and is supported by previous researches on the consequences of the downsizing. The downsizing affected employees' loyalty, perception about the job insecurity and their commitments toward the organization and resulting in the poor performance of the employees as well as the organization. This model has potential implications for further research both empirical testing of the model as well as improvement in the model.

Fernando \& Maria (2011) carried out a research to examine the effect of downsizing on corporate performance, considering a sample of manufacturing firms drawn from the Spanish of business strategies during the 1993-2005 periods. No significant differences in post downsizing performance arise between companies which downsize and those that do not. Likewise, they found that substantial workforce reductions through collective dismissals do not either lead to improved performance levels. Downsizing, therefore, may not be a way for managers to increase performance, particularly in a context like the Spanish one, where the labour market is characterized by a high protection of employees' rights and substantial contract termination cost.

Roderick \& Christopher (2011) carried out a study on the effects of downsizing on labor productivity. The current 
study examines whether organizations showing greater consideration for employees' morale and welfare in the downsizing process experience increased labor productivity. Further, because downsizing diminishes human capital and interferes with an organization's social exchange relationships, we posit that attention to employees' morale and welfare will be particularly important for high-performance work systems (HPWS) that rely on human capital for competitive advantage. We tested our hypothesis with a sample of organizations that had downsized using survey data matched with secondary data. Results support our prediction that organizations with more extensive HPWS can reduce productivity losses from downsizing by heightening their consideration for employees' morale and welfare.

Antonio \&Alassandra (2018) studied the influence of job insecurity on job performance and absenteeism, the moderating effect of work attitudes. The study adopts survey design. Four-hundred and twenty five workers were interviewed with a structured questionnaire. Descriptive statistics was used to analyze the data and multiple regression was used to test the hypotheses. Job insecurity was found to be negatively correlated with job performance and positively with absenteeism. However, work related attitudes moderated only the effect of job insecurity on job performance but not on absenteeism.

Hassan (2015) examined the impact of job insecurity on intention to quit among Syrian private banks employees. Moreover, the mediating role of burnout in the relationship between job insecurity and intention to quit is investigated. A total sample of 172 employees is selected. The research findings indicate that there is a significant positive impact of job insecurity on both job burnout and intention to quit. Additionally, increased levels of burnout significantly affect intention to quit. Finally, the relationship between job insecurity and intention to quit is fully mediated by burnout.

Staufenbiel\&Konig (2010) studied a model for the effects of job insecurity on performance, turnover intention and absenteeism. The model is tested with a sample of 136 German non-managerial employees. A model is tested in which job insecurity is simultaneously a hindrance and a challenge stressor. In particular, job insecurity is proposed to have a predominantly harmful effect on performance, turnover intention, and absenteeism, and it is argued that these effects are mediated by (reduced) work attitudes. In addition, job insecurity is also assumed to affect these behaviours in the opposite way (i.e. a suppressor effect) because job insecurity might motivate employees to make them more valuable to the organization by working harder and being less absent. Data from supervisors (i.e. in-role behaviour and organizational citizenship behaviour), the company's personnel files (i.e. absenteeism), and self-reports (i.e. job insecurity, work attitudes, turnover intention, in-role behaviour, and organizational citizenship behaviour) were used. Structural equation modeling showed that a model that included both negative and positive effects fitted the data best. The negative effect was stronger than the positive effect. The results show that the effects of job insecurity are more complex than previously assumed. In addition, the results also revealed that job insecurity has a significant relationship with absenteeism.

Filipkowski, Monica, Johnson, Merle (2008). Carried out research on comparisons of Performance and Job Insecurity in Union and Nonunion Sites of a Manufacturing Company. The aim of the study was to examine the relationships between measures of job insecurity, organizational commitment, turnover, absenteeism, and worker performance within a manufacturer in Chapter 11 bankruptcy. A positive relationship was found between job insecurity and intentions to turnover, and a small negative correlation was found between measures of job insecurity and organizational commitment. Unobtrusive observations of union and nonunion performance over 4 months showed that nonunion production workers were on-task more frequently, although on-task behavior was high for both. Productivity and quality measures of different factories favored nonunion locations. Although comparisons between sites were constrained by a quasi-experimental design, repeated behavioral and outcome measures within sites showed differential effects when the company announced a plant closing in another state. Job insecurity appeared to be an establishing operation that produced differential effects between union and nonunion sites as well as among individual employees within sites.

Mapira (2016) the study assessed the impact of redundancy on organizational performance at Might Stores. The research wascarried in the form of a case study, in which a sample of 44 employees from a population of 60 employees was used. Randomand purposive sampling procedure was employed in selecting elements from 5 managers and 55 general employees. Questionnaires and interviews were used in triangulation to collect data on the sample. After analyzing the collected data, thestudy unearthed that redundancy negatively affects firm performance and as such organizations must consider alternatives toredundancy say manpower planning, redeployment, loaning out and pay cuts.

Juanita (2014) carried out study on voluntary and involuntary job redundancy and employee performance. The objectives of the study were to examine the effect of voluntary job redundancy on job-search activity, voluntary job redundancy on levels of depression and job attitude. The study employed descriptive survey design. The population 
of the study was two hundred and twenty-two people who had recently become unemployed via a job redundancy (typically because their company was downsized), multivariate analysis of covariance (MANCOVA) was used to test hypotheses one and two. The result found significant differences in job attitudes between voluntarily redundant and involuntarily redundant employees, the results showed that people who were made involuntary redundant experienced higher levels of depression and engaged in less job-search activity than those who left their job voluntarily. The study concludes that job redundancy initiatives need to be designed in ways that engender greater feelings of control. Enhanced control over the process of job redundancy can come through company initiatives such as advance notice, re-training, outplacement, severance packages, and assistance with financial planning.

\subsection{Gap in the Literature}

Several studies have been conducted on organizational downsizing and employee performance but centered on causes of organizational downsizing (Rolf Van and frank et al 2016, Mckinley et al., 2000; Vicente Lorente and Suarez-Gonzalez, 2007). Others on effect downsizing strategy on performance of employees of Barclays bank (Robert \& Anne 2015). Sumera\&Faiza (2015) examined downsizing on job satisfaction of existing employees in banking sector of Pakistan.Asuma\&Ayse (2016) conducted a research on effects organizational downsizing on survivors' commitment. Rehman\&Naeem (2012) have proposed a conceptual model of the after-effects of the downsizing on the survived employees of the organization. Fernando \& Maria (2011) examined the effect of downsizing on corporate performance, Roderick \& Christopher (2011) carried out a study on the effects of downsizing on labor productivity. Antonio \&Alassandra (2018) studied the influence of job insecurity on job performance and absenteeism. Hassan (2015) examined the impact of job insecurity on intention to quit among Syrian private banks employees. Staufenbiel \& Konig (2010) studied the effects of job insecurity on performance, turnover intention and absenteeism. Filipkowski, Monica, Johnson, Merle (2008). Carried out research on comparisons of Performance and Job Insecurity in Union and Nonunion Sites of a Manufacturing Company.Mapira (2016) assessed the impact of redundancy on organizational performance at Might Stores. Juanita (2014) carried out study on voluntary and involuntary job redundancy and employee performance. Despite the existing studies, there is a dearth of study on organizational downsizing and employee performance in selected manufacturing firms in Anambra state, Nigeria. Little attention has been given to some variables of organizational downsizing and employee performance. This study intends to fill this gap by decomposing downsizing into job insecurity and staff redundancy by determining how these components relate to the various indicators of employee performance which includes absenteeism and turnover in selected manufacturing firms.

\section{Methods}

\subsection{Research Design}

This study employed the descriptive survey design. Research design is the plan or blue print on how to go about data collection and analysis, aimed at providing solutions to the problem under investigation. The specific purpose of research design is to obtain data that will enable the researcher to test the hypotheses and answer research questions (Cooper and Schindler, 2011). It involves gathering of opinions and information from respondents which addresses the research objectives and research questions. This study is descriptive survey because it adopted the use of questionnaire aimed at examining the effects of downsizing and employee performance.

\subsection{Sources of Data}

Data for the study was generated from primary sources

3.2.1 Primary Sources of Data: are perceived as first hand information generated to solve specific problems. They are ways of collecting original data for the purpose of the study. They are usually collected from the field under the control and supervision of an investigator. Questionnaire and oral interview were employed to generate data for analytical purposes.

\subsection{Population of the Study}

The target population of the study comprises both senior and junior staff of ten selected manufacturing firms in Anambra state, Nigeria. The population of the study is one thousand, four hundred and twenty eight $(1,428)$. These manufacturing firms include Aloaluminium, Emenite limited, Cutix plc,Juhel industry limited. 
Table 1. Population distribution

\begin{tabular}{lllll}
\hline No. & Selected Manufacturing firms & Senior Staff & Junior Staff & Total \\
\hline 1 & AloAluminium & 121 & 132 & 253 \\
\hline 2 & Emenite limited & 96 & 386 & 482 \\
\hline 3 & Cutix plc & 84 & 450 & 534 \\
\hline 4 & Juhel industry limited & 41 & 118 & 159 \\
\hline & Total & 342 & 1086 & 1428 \\
\hline
\end{tabular}

Source: Human Resource Department (2018)

\subsection{Sample Size}

A sample is a subset containing the characteristics of a large population. Samples are used in statistical testing when population sizes are too large for the test to include all possible members or observation (Asike 2001). In calculating the sample size for this study, the researcher applied the statistical formula for selecting from a finite population. Bill Gooden, (2004) finite population formula is

$$
\mathrm{SS}=\frac{z 2 x(p) x(1-P)}{C 2}
$$

Where

SS = Sample size

$\mathrm{Z} \quad=\mathrm{Z}$ Value (e g 1.96 for $95 \%$ confidence level)

$\mathrm{P}=$ Percentage of population picking a choice expressed as decimal

$\mathrm{C}=$ Confidence interval expressed as decimal $(+4 \%)$

$\mathrm{SS}=\frac{1.96 \times 0.5 \times 0.5}{0.04}$

$\mathrm{SS}=\frac{1428 \times 0.5 \times 0.5}{0.0016}$

$\mathrm{SS}=\frac{1428 \times 0.25}{0.0016}$

$\mathrm{SS}=\underline{357}$

0.0016

$\mathrm{SS}=223.12$

$=223$

New SS = SS

$\underline{1+(\mathrm{SS}-2)}$

POP

Where

POP = Population $(1,428)$

$\mathrm{SS}=223$

New SS $=$

$\underline{1+(223-2)}$ 
New SS $=$

$1+221$

New SS $=\frac{223}{1+1.1555}$

New SS $=\frac{223}{2.1555}$

$\mathrm{SS}=103.456274646$

$\mathrm{SS}=103$

\subsection{Method of Data Analysis}

To analyze the data for this research both descriptive and inferential statistical tools were adopted. The descriptive statistical tool that was employed includes mean, percentage and standard deviation. The inferential statistical tool that was utilized is simple regression analysis. Correlation analysis showcases the interdependence of the study variables. Statistical correlation is significant if the coefficient is more than 0.5 . Moreover, if P- value is low (under 0.01 ), it implies that the correction actually exists.

Decision Rule: The hypotheses accept or reject criterion is based on, if $\mathrm{P}<.01$, we reject the null and accept the alternate but if $\mathrm{P}>.01$, we reject the alternate and accept the null.

\section{Data Presentation and Analysis}

The results are presented in accordance with the research questions, and thereafter a test of the hypotheses that guided the study. The study used a deductive approach, thus, from the review of the effects of downsizing and approaches to its analysis, the specific hypotheses were developed and tested in the study. A summary of the demographic information of the respondents for the study is shown in the Table 2.

Table 2. Demographic information of the respondents

\begin{tabular}{llll}
\hline Demographic profile & & Frequency & Percentage* \\
\hline Gender: & Male & 107 & $48.2 \%$ \\
& Female & 115 & $51.8 \%$ \\
\hline Marital Status: & Married & 121 & $54.5 \%$ \\
& Single & 72 & $32.4 \%$ \\
& Divorce & 29 & $13.1 \%$ \\
\hline Academic Qualification: & Secondary School & 51 & $23.3 \%$ \\
& Diploma & 60 & $27.4 \%$ \\
& Bachelor Degree & 75 & $34.2 \%$ \\
& Master Degree \& Above** & 33 & $15.1 \%$ \\
\hline Years of work experience: & 5 years & 41 & $18.5 \%$ \\
& $6-10$ years & 90 & $40.5 \%$ \\
& $11-15$ years & 57 & $25.7 \%$ \\
& $15 \&$ Above & 34 & $15.3 \%$ \\
\hline Category of Staff: & Senior & 86 & $39.4 \%$ \\
& Junior & 132 & $60.6 \%$ \\
\hline
\end{tabular}

\section{Source: Field Survey (2018)}

* The reported percentage figures are the valid percentages based on the number of valid responses

** Also included in this category are respondents with professional qualifications.

The reliability of the instrument was tested using Cronbach Alpha $(\alpha)$, which is a measure of the internal consistency of a scale. 
Table 3. Reliability statistics

\begin{tabular}{lll}
\hline & $\mathrm{N}$ & Cronbach Alpha $(\alpha)$ \\
\hline Job insecurity: & 5 & .709 \\
Staff redundancy: & 5 & .752 \\
Absenteeism: & 4 & .761 \\
Employee turnover: & 4 & .780 \\
\hline
\end{tabular}

Source: SPSS Ver. 24

The downsizing scale consisted of four subscales, job insecurity subscale consisted of 5 items $(\alpha=.709)$, the staff redundancy subscale consisted of 5 items $(\alpha=.752)$, the The employee performance scale consisted of four subscales, the absenteeism subscale consisted of 4 items $(\alpha=.761)$, the employee turnover subscale consisted of 4 items $(\alpha$ $=.780$ ), indicated a high level of internal consistency (Pallant, 2007).

\subsection{Descriptive Statistics}

Table 4. Descriptive statistics downsizing items

\begin{tabular}{|c|c|c|c|c|}
\hline & Min & Max & Mean & $\begin{array}{l}\text { Std. } \\
\text { Deviation }\end{array}$ \\
\hline $\begin{array}{l}\text { 1. An employee would be more absence to his/her job when he feels } \\
\text { that his job is insecure. }\end{array}$ & 1 & 5 & 4.82 & .497 \\
\hline $\begin{array}{l}\text { 2. Job insecurity improves workers' absenteeism and decreases } \\
\text { performance. }\end{array}$ & 1 & 5 & 4.17 & .590 \\
\hline $\begin{array}{l}\text { 3. Job insecurity increase withdrawal behavior which result in higher } \\
\text { absenteeism, turnover intention and turnover }\end{array}$ & 2 & 5 & 4.64 & .597 \\
\hline $\begin{array}{l}\text { 4. Employees who perceive threat of job security may become less } \\
\text { committed to the organization and may decide to quit the job. }\end{array}$ & 1 & 5 & 4.25 & .626 \\
\hline $\begin{array}{l}\text { 5. An employee has a strong desire to stay in the organization for a } \\
\text { very long time as long as his job is secure. }\end{array}$ & 1 & 5 & 4.59 & .772 \\
\hline $\begin{array}{l}\text { 6. Employee are communicated and consulted in advance on the need } \\
\text { for organization to reduce their workforce. }\end{array}$ & 1 & 5 & 4.35 & .846 \\
\hline $\begin{array}{l}\text { 7. Managers considered employee proficiency through skills, } \\
\text { qualification and standard of work performance when selecting } \\
\text { employee that will be made redundant. }\end{array}$ & 1 & 5 & 4.34 & .879 \\
\hline 8. Fear of redundancy among workers has led to increase in turnover. & 1 & 5 & 4.36 & .751 \\
\hline $\begin{array}{l}\text { 9. Employee who has been selected to be made redundant is notified } \\
\text { in writing that their job has been terminated. }\end{array}$ & 1 & 5 & 4.49 & .780 \\
\hline $\begin{array}{l}\text { 10. Organization loses expertise, knowledge and experience of workers } \\
\text { and these affects the organization performance. }\end{array}$ & 2 & 5 & 4.48 & .560 \\
\hline
\end{tabular}

Source: SPSS Ver. 24 
Table 5. Descriptive statistics employee performance items

\begin{tabular}{|c|c|c|c|c|}
\hline & Min & Max & Mean & $\begin{array}{l}\text { Std. } \\
\text { Deviation }\end{array}$ \\
\hline 11. I absent myself from work without prior permission. & 1 & 5 & 4.02 & 1.296 \\
\hline $\begin{array}{l}\text { 12. I absent myself from work as a result of job insecurity and } \\
\text { unfavourable work attitude. }\end{array}$ & 1 & 5 & 3.95 & .825 \\
\hline $\begin{array}{l}\text { 13. Organisation incurred losses and work scheduled are upset as a } \\
\text { result of my excessive absent. }\end{array}$ & 1 & 5 & 4.55 & .749 \\
\hline $\begin{array}{l}\text { 14. My absence to work undermines the purpose of the company in } \\
\text { terms of productivity and otherwise. }\end{array}$ & 1 & 5 & 4.12 & .774 \\
\hline $\begin{array}{l}\text { 15. Employee turnover results in an extra work load for the remaining } \\
\text { staff. }\end{array}$ & 1 & 5 & 4.63 & .589 \\
\hline 16. Employees who leaves the organization where made redundant. & 1 & 5 & 4.37 & .640 \\
\hline $\begin{array}{l}\text { 17. High employee turnover disrupts normal operations of the } \\
\text { company and causes morale problems which affect the } \\
\text { organisation performance. }\end{array}$ & 2 & 5 & 4.69 & .511 \\
\hline $\begin{array}{l}\text { 18. Employee turnover allows organization to loss competent and high } \\
\text { performed employees }\end{array}$ & 1 & 5 & 4.37 & .669 \\
\hline
\end{tabular}

Source: SPSS Ver. 24

\subsection{Analysis of Research Questions}

Research question one: What is the extent of relationship that exists between job insecurity and absenteeism in selected manufacturing firms in Anambra state, Nigeria?

Table 6. Relationship between job insecurity and absenteeism

\begin{tabular}{ll}
\hline & Correlation Coefficient \\
\hline Job insecurity and absenteeism: & $.664 * *$ \\
$\mathrm{~N}$ & 103
\end{tabular}

Source: SPSS Ver. 24

**. Correlation is significant at the 0.01 level (2-tailed).

The table shows that the extent of relationship between job insecurity and absenteeism in the manufacturing firms is a moderate uphill (positive) relationship (Bryman, 2012). Therefore, job insecurity and absenteeism are significantly positively correlated, $r=.664, p<.01$.

Research question two: What is the extent of relationship that exist between staff redundancy and employee turnover in selected manufacturing firms in Anambra state, Nigeria?

Table 7. Relationship between staff redundancy and employee turnover

\begin{tabular}{ll}
\hline & Correlation Coefficient \\
\hline Staff redundancy and employee turnover: & $.796^{* *}$ \\
$\mathrm{~N}$ & 103 \\
\hline
\end{tabular}

Source: SPSS Ver. 24

**. Correlation is significant at the 0.01 level (2-tailed).

The table shows that the extent of relationship between staff redundancy and employee turnover in the manufacturing firms is a strong uphill (positive) linear relationship (Bryman, 2012). Therefore, staff redundancy and 
employee turnover are significantly positively correlated, $r=.796, p<.01$.

\subsection{Test of Hypotheses}

Hypothesis one: There is a positive relationship between job insecurity and absenteeism in selected manufacturing firms in Anambra state, Nigeria.

The model showed $\mathrm{R}$ square value of .44; and an adjusted $\mathrm{R}$ square value of .41 , from which we can conclude that the overall model is significant with a moderate high explanatory power $\left(R^{2}=.44\right)$. $R^{2}$ measures the proportion of the variance in the dependent variable that is explained by the independent variables, therefore the independent variable explain approximately $41 \%$ of variance in the dependent variable. The results of the regression model are shown in the Table below:

Table 8. Regression results for hypothesis one

\begin{tabular}{lllllll}
\hline & F & Sig. & Unstandardized & Beta & t & Sig. \\
\cline { 3 - 7 } & & B & & & \\
\hline Constant & & & 11.329 & 5.030 & $.000^{* *}$ \\
\hline Model 1: & 5.617 & $.019^{*}$ & .237 & .164 & 2.370 & $.019^{*}$ \\
\hline
\end{tabular}

Source: SPSS Ver. 24

*p $<0.05$

$* * \mathbf{p}<0.01$

The F statistic (ratio of the mean regression sum of squares divided by the mean error sum of squares) which is used to check the statistical significance of the model showed a value of 5.617>3.84; the p value $(p<.01)$ rejects the hypothesis that all of the regression coefficients are zero. The t statistic for the independent variable (job insecurity) is $5.030(t=5.03, p<.01)$, confirming $\mathrm{H}_{1}$; thus, there is a positive relationship between job insecurity and absenteeism in selected manufacturing firms in Anambra state, Nigeria.

Hypothesis two: There is a positive relationship between staff redundancy and employee turnover in selected manufacturing firms in Anambra state, Nigeria.

The model showed $\mathrm{R}$ square value of .63; and an adjusted $\mathrm{R}$ square value of .62 , from which we can conclude that the overall model is significant with a relatively high explanatory power $\left(\mathrm{R}^{2}=.63\right) . \mathrm{R}^{2}$ measures the proportion of the variance in the dependent variable that is explained by the independent variables, therefore the independent variable explain approximately $62 \%$ of variance in the dependent variable. The results of the regression model are shown in the Table below:

Table 9. Regression results for hypothesis two

\begin{tabular}{lllllll}
\hline & F & Sig. & Unstandardized & Beta & t & Sig. \\
\cline { 3 - 6 } & & B & & & \\
\hline Constant & & & 13.809 & 13.922 & $.000^{* *}$ \\
\hline Model 2: & 18.201 & $.000^{* *}$ & .191 & .296 & 4.266 & $.000^{* *}$ \\
\hline
\end{tabular}

Source: SPSS Ver. 24

$* * \mathbf{p}<\mathbf{0 . 0 1}$

The F statistic (ratio of the mean regression sum of squares divided by the mean error sum of squares) which is used to check the statistical significance of the model showed a value of $18.201>3.84$; the $p$ value $(p<.01)$ rejects the hypothesis that all of the regression coefficients are zero. The $t$ statistic for the independent variable (staff redundancy) is $4.266(t=4.266, p<.01)$, confirming $\mathrm{H}_{1}$; thus, there is a positive effect of staff redundancy on employee turnover in selected manufacturing firms in Anambra state, Nigeria. 


\section{Discussion of Findings}

The study investigated the effect of downsizing on employee performance of manufacturing firms in South-Eastern, Nigeria. Studies have shown mixed findings on the subject, some report specific aspects of downsizing as negative and others as positive (Miguda, 2013). Results are based on the nature of the organisation (e.g. product or service), industry and institutional factors, country of origin, among several other factors. For instance, Sumera and Faiza (2015) reported a significant effect of corporate downsizing on job satisfaction in Pakistan, Ngirande, Terera, and Mutodi, (2014) in South Africa, while, Hamed, Bowra, Aleem, and Hussain (2013) found no significant effect of corporate downsizing on financial performance in Pakistan. The correlation results of the study showed a positive correlation between downsizing proxies (job insecurity, staff redundancy, corporate restructuring and redeployment) and employee performance variables (absenteeism, employee turnover, and job commitment). This is consistent with the study by Robert and Anne (2015) in Kenya; that reported a positive correlation between the reduction of employees and employee performance. In contrast, the study by Ikyanyon (2012) on a sample of survivors in Nigeria showed that the relationship and effect of corporate downsizing maybe positive or negative depending of the individuals' perception of the downsizing activity. With a low job satisfaction and high expectancy it is positive; but with a high job satisfaction and low expectancy it is negative.

This is consistent with the study by Carl, Jack, Cynthia, and Michael (2013) in the U.S., which showed that survivors perceived lower organizational performance, job security, affective attachment, and higher turnover intentions than their counterparts. In contrast, the study by Ndlovu, Brijball, and Parumasur (2015) in South Africa showed that corporate downsizing had similar effects on both layoffs and survivors.

The empirical analysis revealed a positive statistically significant effect of job insecurity on absenteeism. The study by Staufenbiel and Konig (2010) in Germany revealed that job insecurity has a significant relationship with absenteeism. However, the effects were complex as revealed from the Structural Equation Model used in the study. Studies have shown that a high degree of job insecurity led to reduced physical and mental health, decreased self-esteem, increased anxiety, depression, psychosomatic complaints, lower life satisfaction and a greater chance of burnout (Chirumbolo \&Areni, 2005; De Witte, 2005). More significantly it accounted for a decreased job involvement and motivation. The study by Antonio and Alassandra (2018) which used a moderator variable, found that job insecurity is negatively correlated with job performance; but, positively with absenteeism. However, work related attitudes moderated the effect of job insecurity on job performance but not on absenteeism. The study by Hassan (2015) in Syria, reported a significant positive impact of job insecurity on intention to quit. The relationship was however fully mediated by burnout. According to the study by Staufenbiel and Konig (2010) in Germany job insecurity may affect turnover intentions in the opposite way (i.e. a suppressor effect) because job insecurity might motivate employees to make them more valuable to the organization by working harder and being less absent. Similarly, Filipkowski, Monica, Johnson, and Merle (2008) documented a positive relationship between job insecurity and turnover intentions, and a small negative correlation between measures of job insecurity and organizational commitment in Union and Nonunion Sites of a manufacturing company.

Other studies, such as Sumera and Faiza (2015) in Pakistan reported a significant effect of downsizing on job security of employees. Hamed, Bowra, Aleem, and Hussain (2013) showed evidence proving that downsizing practices negatively affects the career of employees and the risk of high turnover of employees.

There is a positive and statistically significant effect of staff redundancy on employee turnover in the studied manufacturing firms. Mapira (2016) showed that redundancy had a negative effect on firm performance. Downsizing is an effective way of eliminating redundancies and cutting down on employment costs (Cascio\& Young, 2003; Morris, 1999; Cascio, 1997). For instance the introduction of digital banking products and e-payment platforms and technology, such as the ATM machines in the Nigerian banking sector created staff redundancy in the banks.

As such over time a huge chunk of employees were laid off following the technological innovations. However, the empirical literature provides mixed findings on the effect of corporate restructuring. The study by Malik, Ahmad, and Hussain, (2010) in Pakistan reported a negative correlation between downsizing and job satisfaction of survivors. Juanita (2014) documented evidence on the difference between voluntary and involuntary job redundancy on employee performance, the results of the study showed that people who were made involuntary redundant experienced higher levels of depression and engaged in less job-search activity than those who left their job voluntarily. The study by Oluoch, Michael, and Nyandiga (2013) also found a positive association between surviving a downsizing and job related stress; which eventually translates to low level of commitment among surviving employees'. This is attributed to the survivor syndrome, as espoused by the experimental study of Rolf Van \& Frank et al (2016). Downsizing caused a lower identification with the employer and in turn led to lower employee 
performance. This is also consistent with the study by Jeffrey (2011) in Zimbabwe which examined attitudes and feelings of leavers and survivors following the downsizing process.

\section{Conclusion}

The business environment is continuously changing and organisations are dealing with the after-effects of a global economic slowdown. Organisations are under pressure to change the way they do business in order to remain competitive in a more demanding and cost-controlled environment. Many organisations have turned to downsizing as a strategic decision to realign internal structures with changing macro-environmental factors. The increase in global competitiveness, together with advances in technology and ongoing changes in the environment, requires organisations to continuously adapt and be willing to change their structures, strategies, methods and practices to remain competitive. In some cases they need to transform themselves from rigid bureaucracies into leaner, more flexible operations. Organisational downsizing has recently become an increasingly important issue that needs to be addressed to ensure fair employment practices.

\section{Recommendations}

Based on the findings of the research, it was recommended as follows:

1)The organizations should assured employees who survive the downsizing exercise their job secure this will inbuilt higher self confidence and self efficacy, reduce workers absenteeism and enhance performance.

2) Human resources policies of the organizations should be based on careful forecasting, planning, auditing and implementing. By doing this, it assumed that the actual number of required staff, within the limit of resources of the organization will be employed by the organization at different points in times thereby eliminating or reducing the incidence of arbitrary layoff.

3) Organization should ensure organizational culture that encourages employees' innovation that could enhance the level of productivity; this will enhance the level of organizational productivity and overall performance.

\section{References}

Abssi, C.P., \& Hollman, G. (2000). Job security and job satisfaction as determinants of organizational commitment among university teachers in cross river state, Nigeria. British Journal of Education, 1(2), 82-93.

Aguinis, H. (2009). Performance management (2nd ed.). Upper Saddle River, NJ, Pearson Education Inc.

Ahuja, K. (2006). Personnel management (3rd ed.). New Delhi, India: Kalyani Publishers.

Ali, B. (2008). Impact of job satisfaction on turnover intention: an empirical evidence. Journal of Managerial Sciences, 2(1), 23-41.

Antonio, C., \& Alassandra, U. (2018). The influence of Job Insecurity on Job Performance and Absenteeism: The moderating Effect of Work Attitudes. Journal of Industrial Psychology, 31(4), 65-71.

Applebaum, S.H., Simpson, R., \& Shapiro, B.T. (1999). The tough test of downsizing. Organizational Dynamics, 16(2), 68-79.

Ashford, S.J., Lee, C., \& Bobko, P. (1989). Content cause and consequence of job insecurity: a theory-based measure and substantive test. Academy of Management Journal, 32, 803-829.

Asuman, A., \& Ayse, C. (2016). The Effects of Organizational Downsizing and Layoffs on Organizational Commitment: A Field Research. The Journal of American Academy of Business, 14.

Bosman, J., Buttendach, J., \&Laba, K. (2008). Job insecurity, burntout and organizational commitment among employees of a financial institution in gauteng. Journal of Industrial Psychology, 5(3), 32-40.

Brockner, J. (1998). Managing the effects of layoffs on survivors. Cali. Manage. Rev., 34, 241-261.

Budros, A. (1999). A conceptual framework for analyzing why organizations downsize. Organization Science, 10, 69-82.

Bureau, D.E. (2007). Factors affecting the productivity of building craftsmen studies of Uganda. Journal of Construction Engineering and Management, 13(3), 169-176.

Burne, J.A. (1994). The pain of downsizing. Business Week, 60-69.

Bushra, A.K. (2010). Impact of downsizing on employee attitude and performance. Journal of Independent Studies and Research, 8(1), 157-165. 
Cameron, K.S., Freeman, S.J., \& Mishra, A.K. (1993). Best practices in white collardownsizing: managing contradictions. Aacademy of Management Executive, 5(3), 57-62.

Capelli, P. (1999). Career jobs are dead. California Management Review, 42(1), 146-167.

Carlson, F.R. (2006). The human side of enterprise. New York, Mcgraw Hill.

Cascio, W.F. (1993). Downsizing: What do we know? what have we learned? Academy Management Executive, 7 , 95-104.

Chiavenato, I. (2002). Recursoshumanos (Compact edition). São Paulo: Editora Atlas.

Dewitt, R.A. (1998). Gain and pain, the effect of Australian public sector restructuring. Public Productivity and Management Review, 21(4), 386-402.

Fernando, M.B., \& Maria, J.S. (2011). Does downsizing improve organizational performance? An analysis of Spanish manufacturing firms. International Journal of Management, 19, 301-307.

Ferrie, J.E., Shipley, M.J., Stansfeld, S.A., \& Marmot, M.G. (1997). Effects of chronic job insecurity and change in job security on self-reported health, minor psychiatric morbidity, physiological measures, and health related behaviors in British civil servants. South African Journal of Industrial Psychology, 31(4), 57-64.

Filipkowski, I., Monica, K., Johnson, P., \& Merle, C. (2008). Comparisons of performance and job insecurity in union and nonunion sites of a manufacturing company. Journal of Organizational Behavior Management, 28(4), 218-237.

Freeman, S.J. (1994). Best practices in white collar downsizing: managing contradictions. Academy of Management Executive, 5(3), 17.

Greenberg, J.P., \& Baron, N.J. (2000). Commitment in the workplace, Theory, research and application. Sage Publication, London.

Greenhalgh, L., \& Rosenblatt, Z. (2004). Job insecurity: toward conceptual clarity. Academy of Management Review, $3,438-448$.

Greenhalgh, L., Lawrence, R., \& Sutton, Z. (1998). Job insecurity: toward conceptual clarity. Academy of Management Review, 3, 438-448.

Grimaldi, L. (2005). Study proves recognition pays off. Meetings \& Conventions, 30-40.

Hardy, C. (2001). Strategies for redundancy: Reconciling individual and organizational needs. Canadian Journal of Administrative Science, 3, 275-289.

Harper, A. (2009). Identifying the correct pool for redundancy selection. People Management, 15(23), 61-66.

Harrison, D., \& Price, K. (2004). Context of consistency in absenteeism: studying social and dispositional influences across multiple settings. Human Resource Management Review, 12, 203-225.

Hassan, I. (2015). Job insecurity, burnout and intention to quit. International Journal of Academic Research in Business and Social Sciences, 5(4), 89-92.

Haumann, Y., \&Henry, O. (2007). A review of the literature on employee turnover. African Journal of Business Management, 5(2), 049-054.

Henkoff, R.D. (1994). Healing the wounds overcoming the trauma of layoff and revitalizing downsizing organizations. Jossey- Bass, San Francisco, pp. 248-259.

Huczyunski, A., \& Fitzpatrick, M.J. (2000). managing employee absence for a competitive edge. London, UK: Pitman Publishers.

Hulin, I. (1991). Job insecurity, burnout and intention to quit. International Journal of Academic Research in Business and Social Sciences, 5(4), 89-92.

Huselid, T. (2005). Market orientation and the response of UK financial services companies to changes in market conditions as a result e-commerce. International Journal of Bank Marketing, 19(6), 222-231

Juanita, M. (2014). Voluntary and involuntary job redundancy: Hope or helplessness?. Journal of Applied Management and Entrepreneurship, 7, 25-42.

Kammery, M., Muller, T., \& Arvev, W. (2001). Employee downsizing and organizational innovativeness. International Journal of Human Resource Management. 
Kenney, K.L. (1992). Management made east (1st ed.). South Carolina: Omron Publishers.

Kozlowsky, S.W., Chao, J., Smith, G., \& Hedlund, J. (1993). Organizational downsizing strategies, interventions and research implication. International Review of Industrial and Organizational Psychology, 263-332.

Lee, P.M. (2006). A comparative analysis of layoff announcements and stock price reactions in the United States and Japan. Strategic Management Journal, 18, 879-894.

Littler, S.J. (2000). Effects of job and family characteristics on job satisfaction, job involvement and intrinsic motivation of men and women workers. Journal of Organizational Behaviour, 12(4), 341-563.

Luthan, B.C., \& Sommer, S. (1999). The impact of downsizing on workplace attitude. Academy of Management Journal, 32(1), 115-130.

Mapira, N. (2016). Impact of Redundancy on Organizational Performance. International Journal of Innovative Research and Development, 5.

Mathis, R.L., \& Jackson, J.H. (2009). Human resource management. Mason, Oh, USA: South-Western Cengage Learning.

Mauno, S., Kinnunen, U., Makikangas, A., \& Natti, J. (2005). Psychological consequences of fixed-term employment and perceived job insecurity among health care staff. European Journal of Work and Organizational Psychology, 14(3), 209-237.

Neldyk, A., \& Northcraft, T. (2001). Organisation behaviour. London: Prentice-Hall.

Rehman, W., \& Naeem, H. (2012). Impact of downsizing on the performance of survived employees: A case study of Pakistan. African Journal of Business Management, 6(7), 2429-2434.

Scott, B. (2007). What impact does training have on employee commitment and employee turnover. Kingston: University of Rhode Island.

Shirley, H.J. (2006). Performance contracting: expanding horizons ( $2^{\text {nd }}$ ed.). Lilburn, G.A, Fairmount Press Inc.

Staufenbiel, T., \& Konig, C.J. (2010). A model for the effects of Job insecurity on Performance, Turnover intention and Absenteeism. Journal of Occupational and Organizational Psychology, 83, 101-11.

Sumera, A., \& Faiza, M.S. (2015). Effects of downsizing on job satisfaction of existing employees in banking sector of pakistan. International Journal of Scientific and Research Publications, 5(12), 345-356.

Sverke, M., \& Hellgren, J. (2002). The nature of job insecurity: understanding employment uncertainty on the brink of a new millennium. Applied Psychology: An International Review, 51(4), 23-52.

Teixeira, S. (2010). Gestão das Organizações (2nd ed.). Madrid: Verlag Dashofer.

Tiwari, M. (2014). The nature of job insecurity: understanding employment uncertainty on the brink of a new millennium. Applied Psychology: An International Review, 51(4), 23-52.

Tomasko, W.H. (1987). Psychological contract violations during corporate restructuring. Human Resource Management, 37(1), 71-83.

Wager, T.H. (1998). Exploring the consequences of workforce reduction. Canadian Journal of Administration Sciences, 15(4), 30-39.

Warsi, B.W. (2009). Employee Morale: Not Brain Surgery. Retrieved May20, 2017, from http://www.dfw-r.com

Wiley, C. (1993). Employee Turnover: analyzing employee movement out of the organizations. Washington, D. C: SHRM.

Yu, J.R., \& Park, L.P. (2006). Downsizing: an empirical assessment of survivors' perceptions in a post layoff environment. Organizational Development Journal, 8, 32-43. 